\title{
Tourism Business Strengthening through Agreement with a Goodwill Principle
}

\author{
I Nyoman Sujana \\ Faculty of Law \\ Universitas Warmadewa \\ Denpasar, Bali, Indonesia \\ nyomansujanaa2015@gmail.com
}

\begin{abstract}
This article examines two legal issues relating to the principles of goodwill, namely: whether agreements solely on the basis of goodwill are safe enough to transact in the business field of tourism or not; since every party who transacts in the tourism business sector is subject to different legal systems, what solutions to resolve the business disputes in tourism. The method used to analyze the problem is the normative legal research method. The results show that the world of tourism is inseparable from the business world because the business world may not be able to run orderly and smoothly without going through the agreement. However, the agreement must be done in an orderly manner and based on the principles of goodwill. Thus in the business world, goodwill is a necessity. All actions taken by human beings working in the business world of tourism that frame the action through the making of the agreement must be made on the principles of goodwill. This is in accordance with the provisions of article 1338 paragraph (3) of the $B W$, which stipulates that the agreement shall be executed in goodwill.
\end{abstract}

Keywords—strengthening; tourism business; goodwill

\section{INTRODUCTION}

Bali Provincial Government has made efforts to preserve Balinese culture as one of the world tourism destinations owned by Indonesian nation. As a diverse nation, the people of Indonesia should be proud of having the island of Bali and working together in preserving it, both from the aspect of its natural environment, and a strong culture with the principle of togetherness. As a world tourism destination, tourism actors must participate in efforts to conserve Balinese culture through the application of the philosophy of Tri Hita Karana.

Tri Hita Karana is literally derived from the word Tri, Hita and Karana. Tri means 'three', Hita 'means prosperous, kind, happy, and sustainable', and Karana means 'cause'. Therefore, Tri Hita Karana is the three elements that is the cause of the growth of goodness and prosperity. Building this, Tri Hita Karana is a welfare concept in Balinese life consisting of Parahyangan, Pelemahan and Pawongan. This conception is not only unique but has universal values for Balinese society lives and for the life of nation in Indonesia in general. Balinese society who are mostly engaged in the development of tourism world have instituted "Tri Hita Karana" philosophy in their business practices, for example in Palemahan element, it is seen that the area of tourism and infrastructure have been maintained continuously. Similarly, the relationship between humans is as in Pawowongan concept application, where tourism actors in Bali have framed the business in goodwill; Balinese society, who embrace values in their lives believe in the existence of "Karma".

Local wisdom of Hindus in Bali is a part of culture that has a very diverse form. Various forms of local wisdom vary with values, rituals, folklore, ethics, aesthetics, orders and restrictions. Some forms of local wisdom are still alive and become part of Balinese society's behavior in general because Balinese still believe in karma, a concept that good deeds are rewarded accordingly, i.e., good deeds and vice versa, evil deeds of malicious will not be well also in return. Therefore, in the business world of tourism, the values of local wisdom reflected in the teachings of Hinduism such as Tri Kaya Parisuda, Catur Purusa Artha, and the principles of Tat Twam Asi, greatly affect the business community of its adherents, including when in a business tourism contract.

Balinese residents who mostly embrace the holy teachings of Hinduism must also always underlie business conduct, including building a business in the field of tourism. The business of tourism to be dealt with not only concerns our own nation but also involves a framework for business to go along with Balinese norms and moral ethics. Balinese people also remember the way to seek wealth by believing that their people in making a living, always framed by the teachings of God/Ida Sang Hyang Widi Wasa. If we do good things, we will get a good reward. These are the values of local wisdom that should be the business framework in order to run sustainably.

In relation to business contracts in the field of tourism, it is well understood in advance that in the treaty law, there is an open system and the principle of consensualism, which means that the treaty law provides the widest freedom to the public to enter into agreements containing anything, provided that not violating the public order, and decency. The articles of the treaty law are so-called optimal law, which means that the articles may be removed when desired by the parties making the covenant [1]. An open system, which contains a principle of freedom of the covenant, in the Civil Code is normally inferred in Article 1338 (1) that determines that "all legallymade agreements act as laws for those who create them". 
By the emphasis through the word "all", the chapter seems to contain a revelation of society that the nation of Indonesia is allowed to enter into agreements in any forms containing anything (or about anything) and the treaty will bind those who make it like a law. In other words, in the matter of covenant, everyone is allowed to enact laws for themselves. The article of the treaty law is applied only when we simply do not impose other rules in the covenants we make.

With the freedom of the contract then those who are involved in the tourism business are allowed to make agreements with the users of tourism services (consumers) by making agreements on what is made authentically and through underhand agreements, and even verbal agreements are often made only on the basis of mere beliefs regardless of the impact that will occur in the future whenever one of the parties is defaulting.

In this case, since the parties involved in the tourism business consist of many parties who do not each understand legal issues, there is even the possibility that there are parties that embrace different legal systems due to the differences in citizenship, and transactions are made through social media (online), where the parties do not meet each other. Therefore, if one party takes a default action, the party will be vulnerable to losses that result in an inevitable dispute in the future. As a member of society, everyone generally endlessly maintains its existence in order to stay sustainable and prosperous. That is the reason why every time a deed is used to take profit and loss as a benchmark. Hence, the advantages and disadvantages are used as a guide when performing deeds that are the core of business activities including business in tourism services. As a matter of fact, this does not have to be associated with millions or billions of Rupias. Thus, considering any amount of profits, whether on a large, medium or small scale, is clearly the principle of business activity.

In order for business activities to take place in an orderly and secure manner, in accordance with the human nature as homo economics when a transaction is required, both parties must frame the transaction in goodwill. This is true in the tourism business practices even though the parties have reinforced the attitude with good intentions, but there can be parties who reject what has been agreed upon, or even commit unlawful acts.

Based on the above description, this paper examines the legal issues of whether the agreement on the basis of goodwill is safe or not to perform transactions in the field of tourism business and system or way of dispute settlement in the field of tourism business.

\section{METHOD}

This study was conducted by applying content analysis method in making sense and inference of meaning of laws relating to the tourism business world. To support the existence of data and analysis against it, statute approach and conceptual approach to relevant legislation were used to review the laws and regulations governing business in the world of tourism. The library study was also used to obtain material support in the form of data processed in this study. The library investigation included other materials such as legal dictionaries, language dictionaries, and previous studies relevant to the current study collected through the application of documentation techniques. To obtain an equivalent conclusion, qualitative descriptive research method is used to describe data during analysis, results and to draw conclusions.

\section{Result AND DisCUSSION}

\section{A. Goodwill as the Basis for Transaction Frame in Tourism Business}

Indeed, in any agreement, goodwill is principally realized. In the law of covenant, in addition to the principle of goodwill, a principle called "principle of consensualism" is also applied. This word comes from the Latin word meaning approval. The principle of Consensualism does not mean that a contract is made by agreement. Agreement here means that the two parties have agreed to something done on the principle of goodwill.

The meaning of the principle of consensualism is basically the agreement and the engagement that arose, born from the moment reached by the covenant. In other words, the agreement applies if it has been done with a principal agreement and something in the form of a formality is not enforced. It also implies that the agreement is generally termed "consensus". Sometimes the law provides that for the validity of the agreement, a written agreement (peace agreement) or by notarial deed (agreement on the goods of fixed gratification) is required. However, such a thing is an exception. It is common that treaties imposed with the meaning of binding, buying, exchanging and leasing are consensus agreements. If the principle of consensualism is common, the principle of consensualism is separately inferred from article 1320 of the Civil Code, which determines:

"Untuk sahnyasuatu perjanjian diperlukan empat syarat: 1. Sepakat mereka yang mengikatkan dirinya; 2. Kecakapan untuk membuat suatu perjanjian; 3. Suatu hal tertentu; 4 .suatu sebab yang legal." which means:

"For the validity of a covenant, there are four conditions required: agreement for those who commit themselves; the ability to make an agreement; a certain thing; a legal cause."

Since the provisions of that article do not specify a certain formality in addition to the agreed upon agreement, it is concluded that each agreement is valid (in the sense of "binding") if an agreement has been reached on the subject matter of the treaty.

Against the principle of consensualism, there are also exceptions, namely the Law stipulates certain formalities for some kinds of treaties, on the threat of nullification of the treaty if it does not comply with the form of the intended means, for example: a grant agreement, if the immovable property must be done by notarial deed. Peace agreements must be in writing, and so on. The covenants for which a certain formality is established, are called formal agreements.

By looking upon the business world of tourism, in the interaction between the parties involved in tourism services, it can be understood that the engagement is made from the agreement or contract; some are done authentically under the 
hand or some are done orally. This is in line with the understanding of the agreement as provided for in Article 1313 $\mathrm{BW}$, which affirms that the agreement is an act committed by one or more persons to commit to one or more persons. This indicates that the business activities undertaken by every member of society, whether a small, medium, or large society are always framed by agreement or contact based on the principle of goodwill. This aspect, until now, more enlivened by a growing business entity in the world of modern business in many countries. Being departed from this fact, it is understood that the contract does have a good central position in the field of law itself or in a country's economic system. "The central role of contracts in our legal and economic system happens unintentionally" [2]. That's a piece of Jill Poole's statement against the importance of contracts in the social life of the nuances of business, whether it is natuurlijke natural by natuurlijke rechtreach or recht person.

When examined carefully, in society, an agreement is born from a contract that dominates social life. The subject of the law is bound to the other; some are done deliberately according to plan, and then arranged in interchangeable promises. Initially, there is a party who bid (offterte) if there are other parties who accept (acceptatie), so there will be agreements with a promising result that creates agreements or contracts. The exchanged promises, of course, contain the desired profits. On the other hand, the promises must be met in accordance with the principles of pactasuntservanda. Liability as a result of this achievement, if realized, shall be the rights of the other party, after "vice versa". But if the achievement is a duty that must be met is not enforced, automatic rights of the contract partner will not be realized, and this is certainly detrimental. In signing the agreement with Moch Isnaeni, it is claimed that the essence of human ashomoeconomicus is an unexpected loss, so it is reasonable to be restored, that is by prosecuting the court through a legal base media basis [3].

In order to realize the transactions in the field of tourism business is safe, orderly and smooth, then to avoid any act of suing each other to court in the event of default, it is a good idea for every business contract to be framed by contracts that meet the legal requirements of a contract legally.

In order for such a contract or business transaction to be legally binding upon the parties, it must meet the legal requirements under the contract:

1) Legal requirements in general, consisting of:

a) General legal requirements are based on Article 1320 BW consisting of:

- Will deal;

- Having the right to do;

- Subject matter;

- Legal causes.

b) General legal requirements outside chapters 1338 and 1339 BW consisting of:

- Terms of goodwill;

- Terms according to custom;
- Terms are in accordance with propriety; and

- Terms in accordance with the public interest.

2) Specific legal requirements consisting of:

- Written terms of certain contracts;

- Terms of notarial deeds for certain contracts;

- Terms of deed of a certain official (not a notary public for certain contracts); and

- Terms of permission from the authorized [4].

The legal consequences of non-fulfillment of one or more of the valid terms of the contract vary according to which conditions are violated. The legal consequences are as follows:

- $\quad$ Null and Void (neitig); in the case of violation of objective requirements in Article 1320 of B.W.Such objective requirements are "subject matter" and "legal causation"

- Could be canceled; in the case of non-fulfillment subjective terms to Article $1320 \mathrm{BW}$. The subjective requirements are: "agreement of the parties" and "the ability to act".

- The contract could not be executed; contracts that cannot be executed are contracts that are not simply null and void, but cannot be executed. However, the contract still has certain legal status. The difference with contracts that are null and void, is that unenforceable contracts may still be converted into legitimate contracts. Examples of non-executable contracts are contracts that should be made in writing, but made orally. However, then the contract was written by the parties.

- Administrative sanctions; there is also a contractual requirement which, if not met, only imposed administrative sanctions against either party or both parties in the contract. For example, if a contract requires permission or reporting to a particular agency, such as a license/reporting to an Indonesian bank for offshore loan contract [4].

In addition to the conditions as mentioned above, for the validity of a contract, it is also required that the contract does not violate the element of goodwill, decency, public interest, and custom.

The agreement must be executed under a goodwill. According to the provisions of article 1338 paragraph (3) of $\mathrm{BW}$, the agreement shall be carried out in goodwill (goedertrow, bonafide). The formulation of the provisions of Article 1338 paragraph (3) indicates that goodwill is provided in the case of contract execution, not on the making of the agreement. This is because the element of goodwill in terms of contracting can already be covered by the "legal force" element of the $1320 \mathrm{BW}$ article. Thus, the contract can be made legally in the sense that it is a good thing, right in its implementation or not to harm a third party. In this case, it can be said that the agreement/contract has been implemented contrary to 
goodwill. For example, mortgage agreements should be redeemed for pure gold. So the actual mortgage recipient has enough time to get the lien redeemed forcing the lender to redeem the lien just as the gold price soars. This means when it can still collect payments at a time when the gold price is stable, both before and after the gold price fluctuation, although it is actually made possible by the pledge of the agreement when reading literally. Therefore, it is contradictory to Article 1338 paragraph (3) of BW.

\section{B. Settlement of Disputes in Tourism Business}

In the current era of globalization, where relations between nations appear no longer limited, everything in everywhere can be connected in a competitive way. Similarly, the development of law in Indonesia continues to experience the rapid number of community activities, especially in the field of economy and business.

What often happens in such a situation of rapid development and competition is the emergence of disputes. Disputes are things that have become part of human interaction. Therefore, the frequent disputes in the tourism business of the principals involved are subject to different legal systems. On the one hand, the system of law upheld is in the form of customary law of each region; and there are also foreign laws according to nationality owned. When a dispute arises, it must be settled. The problem is how to resolve the dispute in the field of tourism business because each party is subject to different legal systems, which law should apply? And who is most appropriate to solve the problem? The easiest and cheapest way to solve the dispute is that the dispute party must solve the dispute by consensus. In addition, when it is very difficult to realize this way of deliberation, it must be pursued through forums that exercise the authority of vigilante action.

Settlement of business disputes included among the tourism business in general is an effort that must be run by the entrepreneur itself. Disputes are a logical consequence to the parties binding a business agreement. Therefore, it is advisable to have a dispute settlement clause in every business transaction undertaken.

This is because the parties involved in the tourism business world must include foreigners who each exchanged business transactions subject to different legal systems because of differences in terms of citizenship. Therefore, it will be very important in the agreement to contain a dispute-resolution clause as it will determine how dispute settlement will be made by the parties against any type of dispute that may arise. This will determine which forums are competent to resolve business disputes. As a consequence, the parties can resolve each dispute correctly and correctly in peace. In addition, existing problems can also be solved easily and quickly at a low cost. This way will support the principles that apply in the business world that considers time as money because if the settlement of disputes is done through the courts, it will spend time and cost that is not small. Although there is a simple, quick and inexpensive judicial principle, in practice the principle is still far from reality, because prosecutors feel "winning to char, losing to ashes". Hence, it would be better to solve the problem through the courts than to vigilante.

In the tourism business, contracts actually play an important role because the field of contract law is a very complicated and controversial field of law. However, the main problem in this area is the proper determination of the contract.

To determine the law that must be applied to regulate contract issues, including business contracts in tourism, it can be used as a reference of what has become a principle in the International Civil Law, which are:

- Principle of Lex Loci Contractus; this principle is the oldest principle based on principles of locus regitactum. Based on the principle, "the proper law of contract" is the law of the place of contracting.

- Principle of Lex Loci solutions; it is the variation oflex loci Contractus principle assuming that "the proper law of contract" is the place of execution of the agreement that is more relevant to the contract than the place of agreement.

- Principle of freedom of the parties; this principle is a development of appreciation of the main principles in the law of agreement, that is the principle that everyone basically has the freedom to commit to the covenant (freedom to contract or party autonomy) [5].

- Principle of lexraisitae, it is a determining point that is to determine the applicable law in the case of differences in nationality held in a contract, can also apply the principle of lexraisitae, namely the law where the place is the object of the agreement or place where the location of the material [6].

\section{CONCLUSION}

Based on the above description, it can be concluded that business actors in the field of tourism should frame the transactions that they do with the principle of goodwill; this should be done with the aim to keep the business can still run orderly, smooth and secure, because in the world of tourism business often involves parties who are each subject to different legal systems because of differences in nationality, and this is vulnerable to disputes.

Given that each party that conduct transactions in the field of tourism business is subject to different legal systems, so the settlement of business disputes of the tourism can be done according to the principles of International Private Law, namely: Principle of Lex Loci Contractus; Principle of Lex Loci Solutionist; Principle of freedom to contract or party autonomy; and Principle of Lex Rai Sitae.

\section{ACKNOWLEDGEMENT}

The author would like to thank all the parties who have helped and contributed in the writing of this article, both those who contribute in the form of funding and critical ideas. Hopefully this paper can be useful theoretically and practically for the addition and development of knowledge, especially in the field of legal science. 


\section{REFERENCES}

[1] Subekti, Hukum Perjanjian, PT. Intermasa, Jakarta; 2005.

[2] J. Poole, Textbook on Contract Law, Blackstone Press, London, 2001.

[3] M. Isnaeni, "Implikasi Penuangan Kontrak Sebagai Bingkai Bisnis ke dalam Akta Notariil", A paper for Studium Generale competency test of notary candidate and PPAT, held by master program of notary, graduate program, Warmadewa University, Saturday November 26th, 2016 at Sri Kesari Warmadewa Mandapa room, Denpasar-Bali. 2016.
[4] M. Fuady, Hukum Kontrak, First Edition, PT.Citra Aditya Bakti, Bandung, 2015.

[5] B. Seto, Dasar-Dasar Hukum Perdata Internasional, First Edition, PT. Citra Aditya Baki, Bandung, 1994.

[6] S. Gautama, Hukum Perdata Internasional Indonesia, Jilid III, part 1, Alumnus, Bandung, page 315. 1981. 